$1-3$

ろう付およびマイクロソルダリング*

竹 本

IE $^{* * *}$

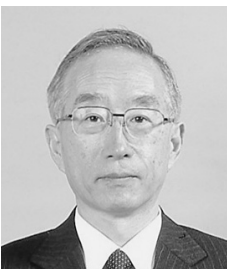

\title{
Brazing and Micro-soldering*
}

by TAKEMOTO Tadashi* ${ }^{*}$

キーワードろう付, はんだ付, マイクロソルダリング，ぬれ，溶解，鉛フリー，フィラー

\section{1.はじめに}

ろう付とはんだ付を総合してろう接1)記され，母材を 溶融させることなく接合できる低温接合技術として古く から多用されてきた。しかし，レーザなど新熱源の出現 や，継手品質並びに性能向上の要求が高くなってきたこ とと対応して，トーチを利用した昔ながらのろう付は日 本における産業規模が縮小しており, 研究対象としても 扱われなくなっている。とはいえ，ろう接には多点を一 括して接合できる特長から，各種熱交換器類の製造には 不可欠の技術として進化している2)側面もあり，技術力の 高い日本での適用が皆無になるわけではない.

一方で，はんだ付は電子部品実装には不可欠のマイク ロソルダリング技術3)として，ここ20年間に，材料，機器 およびプロセスの三点セットで格段の発展を遂げてきて
おり，今も日本の電気・電子産業を支える重要技術とし て進化している ${ }^{4-7)}$.

本稿では，多点一括接合ならびに低温接合技術として 発展しているろう付およびマイクロソルダリングを念頭 に置き，ろう接の基礎論を記述する。

\section{2.ろう付とはんだ付}

\section{1 定義と特徵}

ろう付とはんだ付は使用する溶加材（溶融させて母材 を接合する材料でろうおよびはんだ）の液相線温度 $450^{\circ} \mathrm{C}$ で区分され，両者を併せてろう接と標記される1). 両方と も，(1)接合母材の融点以下で接合する，(2)わゆるぬれ が接合のきっかけあるいは継手品質に大きく関与する, など接合の原理原則は類似しているが，異なる点も多々 ある。その一例を表 1 に示す。接合界面組織としては,

表 1 ろう付とはんだ付の定義と区分およびそれぞれの差異や特徵など

\begin{tabular}{|c|c|c|}
\hline 定義·区分 & ろう付 & はんだ付 \\
\hline \multirow{2}{*}{ 溶加材の名称と定義 } & ろう(filler, brazing filler metal, brazing filler alloy) & はんだ(solder) \\
\hline & 液相線温度 $450^{\circ} \mathrm{C}$ 以上 & 液相線温度 $450^{\circ} \mathrm{C}$ 未満 \\
\hline 溶加材と母材との反応 & 通常は固溶体を形成 & Sn 基のはんだは通常金属間化合物を形成 \\
\hline 接合界面の特徴 & 溶融溶加材中への母材のエロージョン & 金属間化合物形成に伴う脆さ \\
\hline フラックスの活性度 & 高い & 低い \\
\hline フラックス残さの腐食性 & 強い & 弱い \\
\hline \multirow[b]{2}{*}{ 作業中の酸化および還元 } & 酸化速度が速い & 酸化速度は遅い \\
\hline & $\begin{array}{l}\text { 水素ガス雾囲気など還元雰囲気中作業では還元能力 } \\
\text { は大きい }\end{array}$ & 例え水素雰囲気中であっても還元能力は低い \\
\hline 接合継手の使用温度 & ろうの $0.5 T_{\mathrm{m}}$ を超えることはめったにない & しばしば，はんだ材料の $0.8 T_{\mathrm{m}}$ を超えて使用される \\
\hline 主な用途 & 各種熱交換器類、パイプ、各種工業製品、装飾品 & 電気・電子機器 \\
\hline
\end{tabular}

注）溶加材（フィラー） は、厳密にはろうおよびはんだの両者を総称する言葉であるが、多くの場合（特に英文では）、ろうを指す。 $T_{\mathrm{m}}:$ 絶対温度 $(\mathrm{K})$ で表記したフィラーの融点 
ろう付ではろう／母材界面に母材の固溶体が形成されて いる例が多いが，Sn 基はんだ付では金属間化合物が形成 される. ろう付用フラックスは塩化物・フッ化物など腐 食性の極めて高い無機フラックスが使用され，活性力が 高いけれども，はんだ付では腐食性の極めて低いロジン ベースの有機系フラックスが主流であり，ろう付用フラ ックスに比べると活性力が低いので，ぬれ性の確保が重 要となる. ろう付は温度が高いので, 酸化しやすいが還 元性䨌囲気中では還元速度も速い。はんだ付では，低温 作業なので酸化速度は遅いが還元䨌囲気を使用しても還 元能力は弱い. ろう付継手がろうの融点 $\left(T_{\mathrm{m}}\right.$, 単位 $\left.\mathrm{K}\right)$ の $0.5 T_{\mathrm{m}}$ を超えて使用されることはほとんど無いが，は んだ付継手では常に $0.5 T_{\mathrm{m}}$ を超えて使用されており, 0.8 $T_{\mathrm{m}}$ を超えることも珍しいことではない. どちらも多点一 括接合に強みがあるが，ろう付は熱交換器類のフィン／ プレート（チューブ）接合，はんだ付はプリント基板へ の部品実装に不可欠のキーテクノロジーである.

\section{2 ろうおよびはんだ}

図 1 に，JIS に規定されている各種ろうおよびはんだの 最高液相線温度および最低固相線温度を組成あるいは系 別に示す．最低融点ろうはアルミニウムろう（表中の略 記：BAl）であり，最高液相線はパラジウムろう（BPd） である。

熱交換器製造用など主要なろう付に利用されるろう材 料の組み合わせを表 2 に示す。我が国で最大のろう付産 業は，自動車用各種アルミニウム熱交換器類の製造であ り，Al-Si 系ろうを3003(Al-Mn) 系合金とろう付してい る. 主要ろう付法は, $\mathrm{KAlF}_{4}-\mathrm{K}_{2} \mathrm{AlF}_{5} \cdot \mathrm{H}_{2} \mathrm{O}$ 系非腐食性フラ ックスによる窒素ガス雾囲気中でのろう付である。エバ ポレータは真空ろう付される。瞬間湯沸かし器ではりん
銅ろうを用いて銅がろう付される。その他, 耐食性や耐 熱性が必要な箇所には母材として, ステンレス鋼, チ夕 ン，ニッケル基合金などが使用され，真空ろう付される.

表 3 は，ろうおよびはんた（フィラー）の供給形状の 分類と変遷を示す. 初期はフィラー単体であり, その後, フィラーは母材またはフラックスと合体して供給される ようになる。ろう接技術の進化と材料形態の変遷とは密 接に対応しており，アルミニウム熱交換器製造にはブレ ージングシート, 高密度電子基板実装にはソルダペース トの開発が不可欠となっている．ステンレス鋼や $\mathrm{Ni}$ 基超 合金のろう付には非晶質ろうや粉末が使用される。

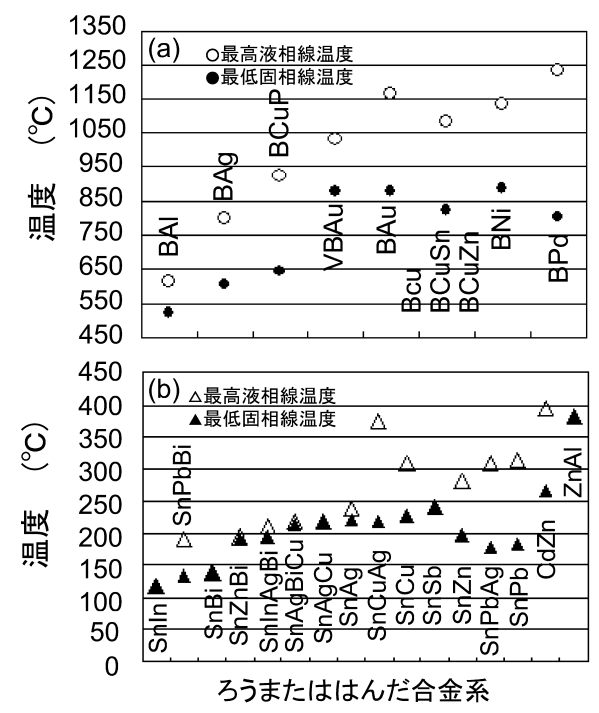

図 1 JIS に規定されるろう（a）およびはんだ (b) の各合金系における液相線温度の最高 値と固相線温度の最低値

表 2 熱交換器類および主要ろう付に使用されるろう

\begin{tabular}{|c|c|c|c|}
\hline 熱交換器の使用分野 & 主要万う合金系 & 主要母材 & 主なろう付方法 \\
\hline \multirow{2}{*}{$\begin{array}{l}\text { 自動車（ラジエータ, エバポレータ, コンデンサ, オ } \\
\text { イルクーラー, その他) }\end{array}$} & Al-Si & アルミニウム合金 (A 3003, A 1100) & $\begin{array}{l}\text { 炉内ろう付, 非腐食性フラックス } \\
\text { 法, 窒素ガスろう付 }\end{array}$ \\
\hline & Al-Si-Mg & アルミニウム合金(A 3003, A 1100) & 真空 \\
\hline 瞬間湯沸加し器 & $\mathrm{Cu}-\mathrm{P}, \mathrm{Cu}-\mathrm{Ag}-\mathrm{P}$ & 銅 & フラックスレス \\
\hline インタークーラー & $\mathrm{Cu}-\mathrm{Ni}-\mathrm{Sn}-\mathrm{P}$ & 銅, 黄銅 & フラックスレス, 雰囲気ろう付 \\
\hline 化学プラント & Ni-Cr-Si-P & ニッケル基超合金 & 真空 \\
\hline 高圧流体, アンモニアチラー & Ni-Cr-Si-P & ステンレス鋼 (SUS 316, 304, 321) & 真空 \\
\hline $\begin{array}{l}\text { 海水用, 船, 薬品製造ライン, 超純水製造, 化学工業, } \\
\text { 医用機器 }\end{array}$ & チタン基, $\mathrm{Ti}-\mathrm{Cu}-\mathrm{Ni}$ & 純チタン, チタン合金 & 真空 \\
\hline
\end{tabular}

表 3 ろうおよびはんだの各種形状の分類とその変遷, 【】内は進化の方向

\begin{tabular}{|c|c|c|c|c|c|}
\hline \multirow{2}{*}{ 世代 } & \multicolumn{2}{|r|}{ 万う } & \multicolumn{3}{|c|}{ はんだ } \\
\hline & ろう+母材 & ろう+フラックス & フィラー単体 & はんだ+母材 & はんだ+フラックス \\
\hline $\begin{array}{l}\text { 初代 (第一 } \\
\text { 世代) }\end{array}$ & & & $\begin{array}{l}\text { 塊 (インゴット), 棒, 竿, 線, 板, } \\
\text { 粒, 粉末, 【各種プリフォーム】 }\end{array}$ & & \\
\hline 第二世代 & $\begin{array}{l}\text { ブレージングシート* } \\
\text { (ろう (皮材) を母材 } \\
\text { (心材) にクラッド }\end{array}$ & $\begin{array}{l}\text { フラックス含有線材（ほと } \\
\text { んど普及せず） }\end{array}$ & 非晶質ろう & 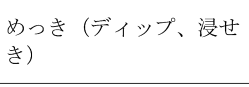 & $\begin{array}{l}\text { やに入りはんだ（線はんだの中 } \\
\text { にフラックス）【線径の減少】 }\end{array}$ \\
\hline 第三世代 & $\downarrow$ 【薄肉化, 組織制御】 & $\begin{array}{l}\text { ペースト*（粉末十非腐食 } \\
\text { 性フラックス） }\end{array}$ & $\downarrow \quad \downarrow$ 微細はんだボール & $\downarrow$ & $\begin{array}{c}\text { ソルダペースト（はんだ粉末 } \\
\downarrow+\text { サラックス)【粉末サイズ } \\
\text { の減少、非酸化粉末の使用】 }\end{array}$ \\
\hline 現代 & $\downarrow$ & $\begin{array}{ll} & \text { ペースト* } \\
\downarrow & (\mathrm{Si}+\text { フラックス })\end{array}$ & $\begin{array}{l}\downarrow \text { 【微細鉛フリー } \\
\text { はんだボール】 }\end{array}$ & 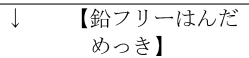 & $\begin{array}{c}\downarrow \downarrow \text { 【鉛フリーやに入りはんだ } \\
\text { およびソルダペースト }\end{array}$ \\
\hline
\end{tabular}




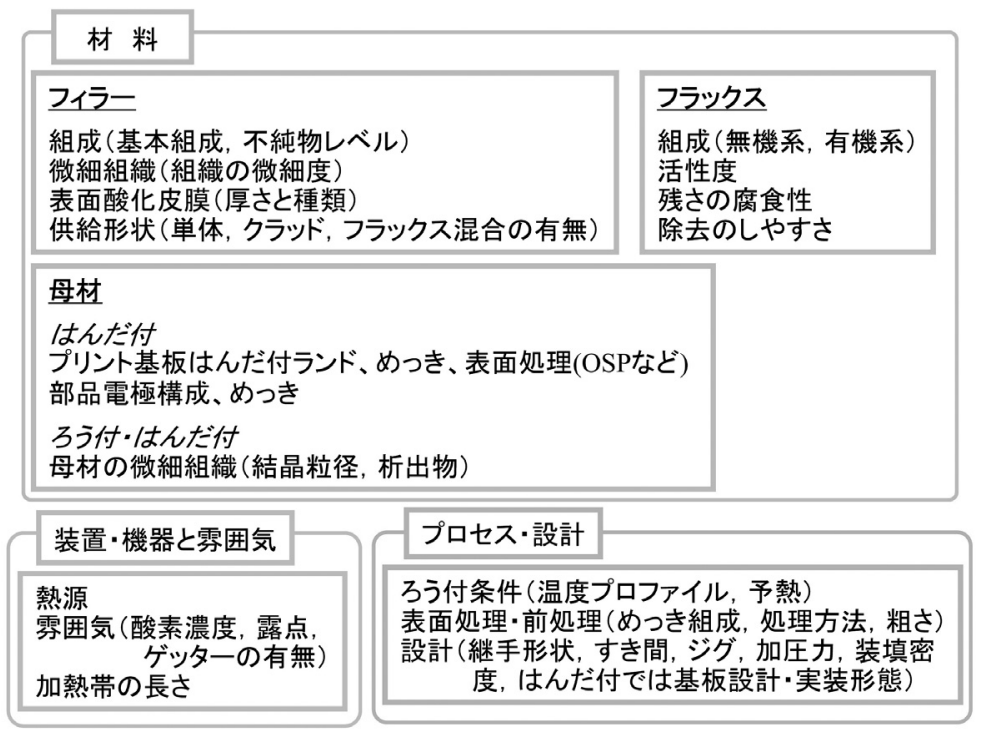

図 2 ろう接において重要な三要素と各影響要因

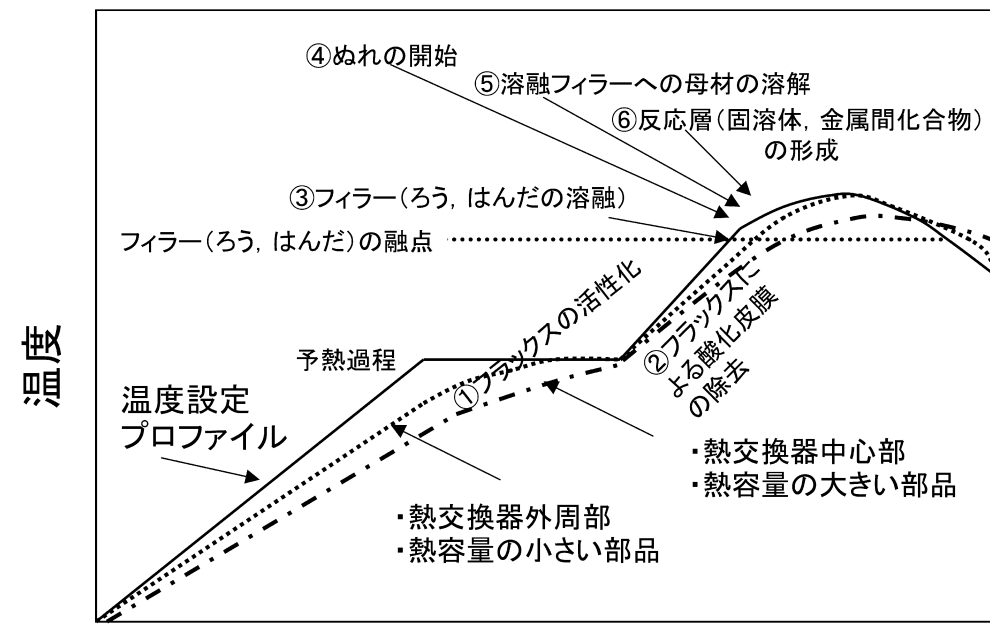

時間

図 3 一般的な多点一括炉内ろう接における温度設定プロファイルの一例と ろう接時に生じる現象および炉内のろう接実体における温度上昇の差異

はんだでは Sn-In が最も低融点で，Zn 系が最高融点を もつ. 現在, EU (欧州連合) の有害物質規制 $\left(\mathrm{RoHS}^{8)}\right)$ に関係して，電気電子機器では $\mathrm{Pb}, \mathrm{Cd}, \mathrm{Hg}$ 等の有害物 質含有はんだは基本的に使用できない。電気・電子機器 実装用はんだについては，いわゆる鉛フリーはんだが記 載されている JIS Z 3282 (2006)「はんだー化学成分及び形 状」を参照願いたい9).

微細・微小電子部品をプリント基板上に実装するいわ ゆるマイクロソルダリング3では，はんだ付技術が製品の 信頼性に直結しており，特に，現在の鉛フリーはんだ付 では日本の優れた製造技術が世界の信頼を得ている。図 2 にろう接における重要因子を示す。材料（フィラー, フラックス, 母材), 装置・機器と雲囲気およびプロセ ス・設計が三要素であり，詳細は省くがこれらの各因子 のいずれが劣っていても健全な継手は得にくい.

\section{3. ろう接の原理}

\section{1 ぬれ}

フラックスを用いる一般的な多点一括接合用炉内ろう 接過程を図 3 に示す. 各接合部において接合過程が同時 に進行することが望ましいために，接合対象品全体を均 一加熱することが大事であり，予熱工程を含めた温度プ ロファイルの設定がノウハウとなる．温度上昇に伴い， (1)フラックスの活性化と, (2)それに伴う酸化皮膜除去が フィラーの溶融前に完了する. (3)フィラー溶融後, (4)母

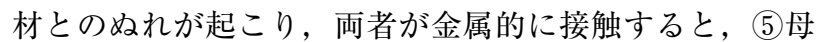
材の溶融フィラーへの溶解が始まる，6同時に界面には 固溶体や金属間化合物の反応層を形成してろう接が完了 する. 


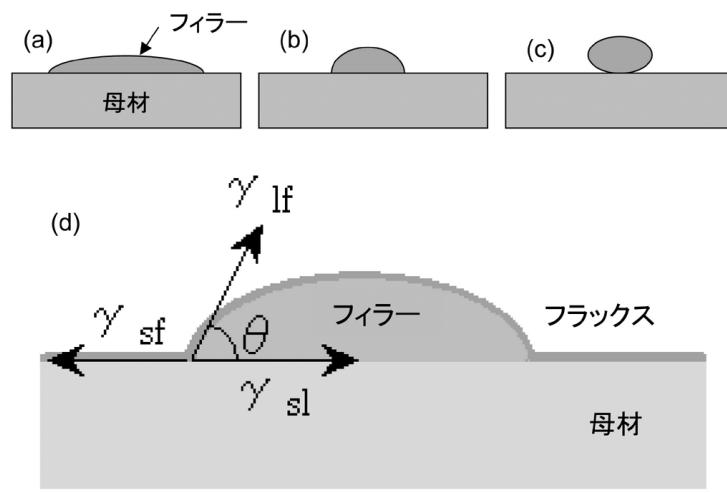

図 4 一般的なぬれの説明図，良好なぬれ（a）, あまりよくぬれない（b)，ぬれない（c）お よび, フラックスろう接におけるぬれの Young の式を用いた釣り合いの説明図（d）

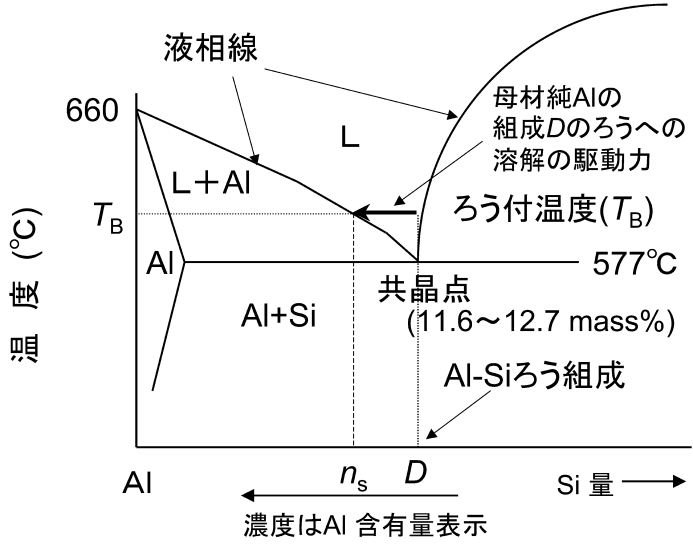

図 5 Al-Si ろうを用いて純アルミニウム母材をろ う付するときの, ろうへの母材の溶解の駆 動力に関する Al-Si 二元状態図による説明
ぬれを促進するフラックスの役割を簡単にいうと腐食 作用による酸化皮膜除去である．例えば，活性成分とし てハロゲン化物を使用すると式（1）のように，フラック スに可溶なハロゲン化物を形成して除去することにより， 下地の酸化していない活性な金属を出現させ，溶融フィ ラーと母材との如を促進する.

$$
\mathrm{MO}+2 \mathrm{HX} \rightarrow \mathrm{MX}_{2}+\mathrm{H}_{2} \mathrm{O}
$$

ここに, $\mathrm{M}$ ：二価の金属 $\mathrm{X}$ ：一価のハロゲン

古典的な説明では図 4 に示すように，ぬれの良否がろ う接性を左右しており，接触角を低下させることが良好 なろう接のキーポイントとされる.フィラーの表面張力 を下げることが有効な対策の一つであり, 活性力の強い フラックスの使用，フィラーへの表面張力低下元素の添 加などが試みられる。

図 4 (d) に扮ける液滴（フィラー融液）と固体（母材） の釣合いは, Young の式で表される.

$$
\gamma_{\mathrm{sf}}=\gamma_{\mathrm{lf}} \cos \theta+\gamma_{\mathrm{sl}}
$$

ここに， $\gamma_{\mathrm{sf}}$ :母材 /フラックス間の界面張力

$\gamma_{\text {lff }}:$ 溶融フィラー/フラックス間の界面張力

$\gamma_{\mathrm{s} 1}:$ 溶融フィラー / 母材間の界面張力

$\theta:$ 接触角

変形すると，

$$
\cos \theta=\left(\gamma_{\mathrm{sf}}-\gamma_{\mathrm{sl}}\right) / \gamma_{\mathrm{If}}
$$

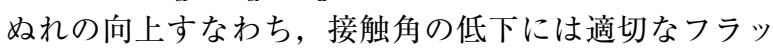
クスを用いて $\gamma_{\text {If }}$ 低下させることが一つの解決策であ り，マイクロソルダリングに扔ける好向上対策として 有効な手法である.

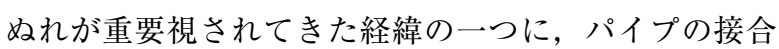
などでフィラーを隙間に十分浸透充填することが, 継手 強度やリーク防止に有効であったことがあげられる。し かし, 熱交換器類のフィンと板あるいはチューブとの接 合に㧍いてはフィラーが長距離を浸透充填する必要は無 い.旧来型のスルーホール基板のはんだ付ではスルーホ 一ル内をはんだが良好に好，基板上面で十分なフィ レットを形成するまで上昇することが望ましく，ぬれ性 の確保が重要となっているが, 最近の表面実装ではすき 間浸透性よりもフィレット形成能力の方が大事である.
基板スルーホール内の奾がりは毛管上昇と類似の 過程で, 基板スルーホール壁と挿入されたアキシャルリ ードの隙間を溶融はんだが上昇していく．溶融フィラー の毛管上昇高さは静水圧の式とラプラスの式から求まる 3).

$$
h=2 \gamma \cos \theta / \rho g r
$$

\section{ここに, $h$ : 毛管上昇高さ}

$$
\begin{aligned}
& \gamma: \text { 液体 (はんだ) の表面張力 } \\
& \theta: \text { 毛管 (スルーホール) との接触角 } \\
& \rho: \text { 液体 (はんだ }) \text { の密度 } \\
& g: \text { 重力 } \\
& r: \text { 毛管 }(\text { スルーホール) の半径 }
\end{aligned}
$$

式（4）から，好が良好なほど（接触角 $\theta$ が小さいほ ど）上昇高さは大きくなることが明かである.

\section{2 溶融フィラーと母材間の反応}

溶融フィラーと母材がぬれた後は，母材とフィラー間 の金属学的な反応が進行する．これを $\mathrm{Al}-\mathrm{Si}$ 二元状態図で 例示したのが図 5 である. $\mathrm{Al}-\mathrm{Si}$ 共晶ろう（Al 濃度 $D$ ) を 用いて温度 $T_{\mathrm{B}}$ で純アルミニウムをろう付すると, 溶融ろ うが図 5 の矢印で示した $\mathrm{Al}$ 濃度 $n_{\mathrm{s}}$ に到達するまで母材の 純アルミニウムが溶融ろう中に溶解する。いわばろうの 濃度が濃度 $n_{\mathrm{s}}$ に達するまで, 母材アルミニウムが溶解し ろうの $\mathrm{Si}$ 濃度を薄め続けることになる。溶解反応は次式 で表すことができる10, 11).

$$
d C / d t=K(A / V)\left(C_{\mathrm{s}^{-}} C\right)
$$

ここに,

$$
\begin{aligned}
& C: \text { 反応時間 } \mathrm{t}(\mathrm{s}) \text { 後の液体中の溶質濃度 } \\
& K: \text { 定数 } \\
& A: \text { 固体と液体の界面積 } \\
& V: \text { 液体の体積 } \\
& C_{\mathrm{S}}: \text { 液体中の飽和溶質濃度 }\left(\text { 図 } 5 \text { における } n_{\mathrm{s}}\right.
\end{aligned}
$$

一定のろう付（実験）条件下では, $K, A, V$ が決まっ ているので, $C_{\mathrm{s}}-C$ が溶解の駆動力であることは式から明 かである. 図 5 の矢印はこのろう付条件における溶解の 駆動力に対応し, 式 (5) の $C_{\mathrm{s}}-C$ に対応する. 純 $\mathrm{Al}$ 母材 は，万うとの界面で $\mathrm{Si}$ を含有する固溶体を形成する.

ろう付よりも低温接合であるはんだ付においても図 6 


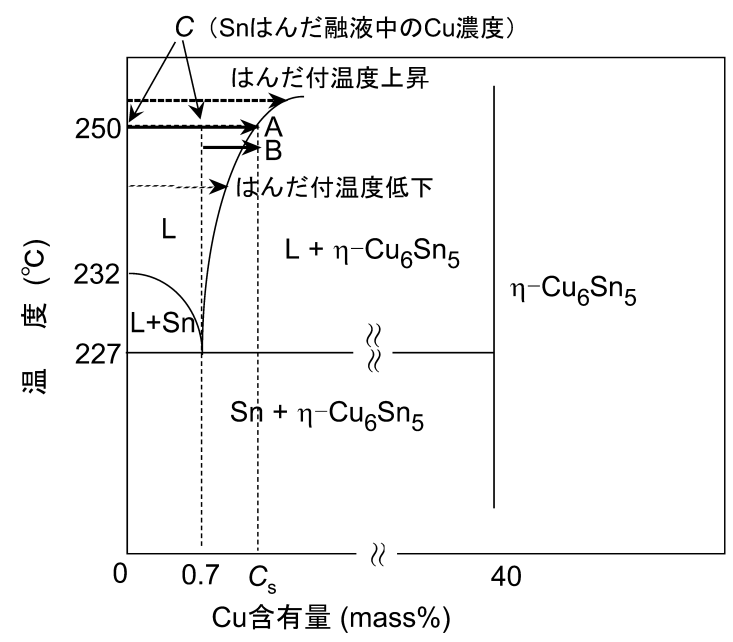

図 6 Sn-Cu 二元状態図を用いた溶融はんだへの Cu 溶解の説明, 純 Snはんだを用いて Cu を $250^{\circ} \mathrm{C}$ ではんだ付するとき， $\left(C_{\mathrm{S}}-C\right)$ は矢印 A に対応, Sn-0.7Cuはんだを用いると $\left(C_{S^{-}}\right.$ C）は矢印 B となり小さくなる, 同様に, はん だ付温度上昇で $\left(C_{\mathrm{S}}-C\right)$ が大きくなり，はんだ 付温度低下では小さくなる。 $\left(C_{\mathrm{S}}-C\right)$ が溶解の 駆動力であることがよくわかる

に，Cu母材を純 Sn ではんだ付する例を示すように溶解 が生じる。溶解の駆動力は矢印 A であり， $250^{\circ} \mathrm{C}$ のはん だ付では，はんだ中の $\mathrm{Cu}$ 濃度が $C_{\mathrm{s}}$ に達するまで母材の $\mathrm{Cu}$ が溶解し続ける。もし, 純 $\mathrm{Sn}$ の代わりに, $\mathrm{Sn}-0.7 \mathrm{Cu}$ 共晶はんだを使用すると，溶解の駆動力は矢印 B となり, 母材の溶解は減少する。目材の溶解抑制を目的に母材元 素をフィラーに添加しておくことは有効であり ${ }^{122}$, Ni-P, $\mathrm{Ni}$ めっき, $\mathrm{Cu}, \mathrm{Ag}$ などの溶解速度のはんだ組成依存性 が報告されている13-16.

接合温度上昇により溶解量が増大することは図 6 に示 すように，駆動力 $C_{\mathrm{s}}-C$ の増大で説明することができる. 逆に，接合温度の低下により溶解量が少なくなることも 駆動力 $C_{\mathrm{s}}-C$ の縮小と対応することが明かである。

同様に，図 5 に示したアルミニウムろう付では $\mathrm{Si}$ 濃度 の低い亜共晶ろうを使用すれば母材アルミニウムの溶解 量は減少でき，ろう付温度の上昇は駆動力が大きくなり， 溶解量も増える。

Sn 基はんだを用いたはんだ付では接合界面に $\mathrm{Cu}$ ある いはめっき材料との金属間化合物を形成し，一般的にそ の厚さが厚くなると継手の機械的性能劣化となる(図 7 17) ので，母材やめっき材料の溶解量は少ない方が好ましい. 可能な限りの低温短時間はんだ付が基本となる。

アルミニウムろう付では母材の溶解とそれに続く母材 へのろう成分（代表的には $\mathrm{Si}$ ）の母材中への拡散が，熱 交換器など多段ろう付における素材の座屈要因となるこ とはもちろん, 薄肉フィンの機械的劣化やいわゆる溶け 落ちなどを招くため，ろうと母材の反応は抑制した方が よい。溶融フィラーと母材間における溶解扔よび拡散の 両反応をエロージョン (侵食) と表現する ${ }^{18}$.

エロージョン速度（量，深さ）には，フィラーおよび 母材組成，温度が関係することはもちろん，母材結晶粒

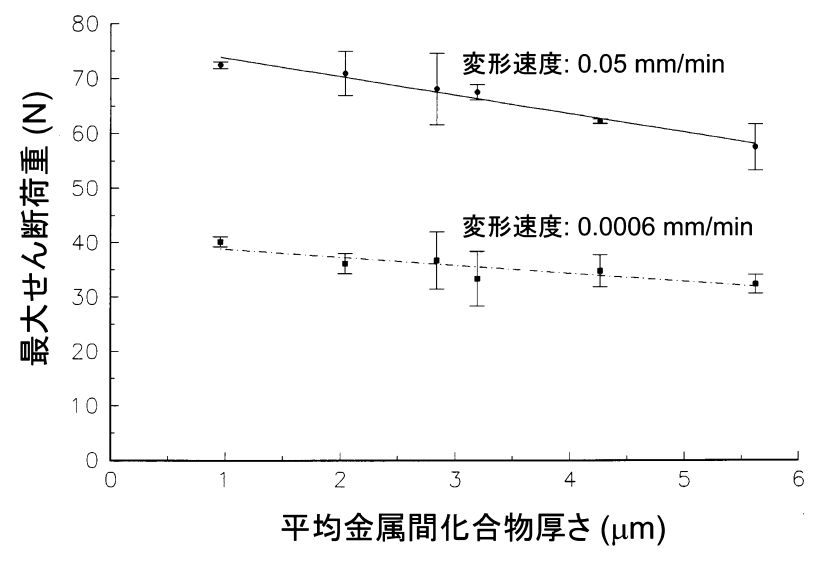

図 7 リードレスチップキャリア表面実装は んだ付継手部における継手強度と金属 間化合物平均厚さの関係 ${ }^{(7)}$

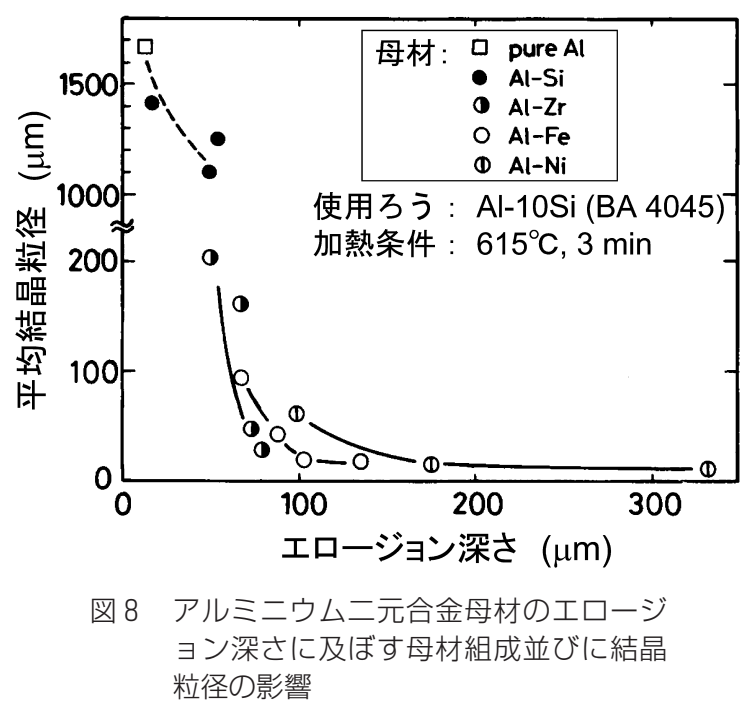

径などの微細組織が影響する ${ }^{18)}$. 図 8 は, アルミニウム合 金のエロージョン媣さに及ぼす母材組成並びに結晶粒径 の影響を示す ${ }^{18)}$. 各元素添加量は 0.05〜最大 $2 \mathrm{at} \%$ の範囲 であり元素によって最大および最小添加量に差がある. 図 8 から, エロージョン深さは母材組成に影響を受ける と共に，結晶粒径が小さくなると共に大きくなることが 明かである，さらに，アルミニウム合金においては，ア ルミニウムと金属間化合物を形成する $\mathrm{Zr}, \mathrm{Fe}, \mathrm{Ni}$ よりも 固溶体を形成する $\mathrm{Si}$ の方が, 同一結晶粒径におけるエロ ージョン深さが大きい傾向となっており， Zr， Fe， Ni の 影響を同一粒径で比べると， $\mathrm{Zr}<\mathrm{Fe}<\mathrm{Ni}$ の順といえよ う.

ろう付におけるエロージョン，はんだ付における金属 間化合物成長のいずれもが継手性能や品質を劣化させる. このため，ろう接では「十分なぬれを確保しつつできる だけ低温短時間接合を行う」ことが基本となる．熱交換 器，プリント基板など大型品や熱容量の異なる部品の搭 載では均一加熱が困難となり，熱交換器周辺部や熱容量 の小さい部品などでは温度上昇が速く, 高温長時間接合 ${ }^{19}$, 熱交換器中心部や熱容量の大きい部品などでは温度上昇 が遅く，低温短時間接合となる。当然，後者において十 
分なぬれと継手品質を確保することを最重点として接合 温度プロファイルが設定されるから，高温長時間接合部 の過剩エロージョンや金属間化合物成長抑制のために均 一加熱が極めて大事となる.

図 3 のろう接温度プロファイルにろう付物実体の温度 上昇を模式的に併示した。熱交換器外周部や熱容量の小 さい部品では温度上昇が速いが，熱交換器中心部（内部） や熱容量の大きい部品では温度上昇が遅くなる．接合不 良を出さないために，温度上昇の遅い部分が十分にぬれ るように温度プロファイルを設定するので, 温度上昇し やすい部分では，高温長時間接合となる。この部分での 過剩反応抑制が大事となる.

\section{3 フィレット形成}

ろう接におけるフィレット（すみ肉）の大小は継手強 さや機械的信頼性と関係するため接合性の目安とされる. この大きさはフィラーの物理定数である程度決まる。図 9 は溶融フィラー融液中に無限長さの垂直板を浸せきし たときに，板とフィラーが接触角 $0 \mathrm{rad}$ でぬれた場合のフ イラーの上昇メニスカス形状をいくつかの代表的なろう およびはんだについて示す ${ }^{20)}$.

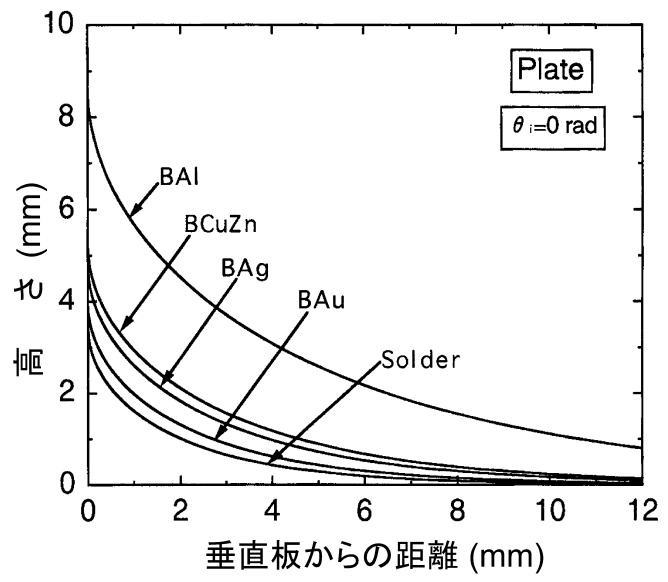

図 9 フィラー融液中に垂直に浸せきした無 限板に,フィラーが接触角 O rad でぬ れ上がった場合のメニスカス形状，最 大上昇高さは距離 O mm における值 で, アルミニウムろう (BAl) が最大で はんだ (solder) が最低值を示す。
垂直板に最も高くぬれ上がるのがアルミニウムろう (Al-12Si）で，最も上昇高さが低いのがはんだ（Sn-37Pb） であり, 接触角 $0 \mathrm{rad}$ でぬれた場合の最大上昇高さは次式 で表される。

$$
\sqrt{2 \gamma / \rho g}
$$

ここに, $\gamma:$ 液体 (はんだ) の表面張力

$\rho:$ 液体（はんだ）の密度

$g:$ 重力

ここで，代表的な $\mathrm{Sn}-3.0 \mathrm{Ag}-0.5 \mathrm{Cu}$ 鉛フリーはんだ $\left(\gamma: 0.5 \mathrm{~N} / \mathrm{m}, \quad \rho: 7400 \mathrm{~kg} / \mathrm{m}^{3}\right)$ で最大上昇高さを求める と, $3.7 \mathrm{~mm}$ となり, 従来の $\mathrm{Sn}-\mathrm{Pb}$ 共晶 $(3.1 \mathrm{~mm})$ よりは わずかに大きくなる.

図 9 から，アルミニウムろうは最も大きなフィレット を形成できることになるが，逆にはんだでは大きなフィ レット形状は期待できない。もちろん実際にはぬれが劣 ることや凸接合面の曲率の影響で上昇高さは図 9 よりも 低くなる ${ }^{20)}$.アルミニウムろうが大きなフィレット形成能 を持っていることは熱交換器の性能向上には有意義であ ることを示している.

\section{3 j 付}

図10にろう付方法に関する分類例を示す. 熱源, 機器, プロセスおよび雲囲気別分類がある. 熱交換器類のろう 付は炉内ろう付であり，フラックス使用の有無やフラッ クスの種類などろう付雲囲気によって呼称が変わる2).

図 2 に示したように, 材料, プロセス, 機器の三要素 の組み合わせにより接合性は変わるので，それぞれ用途 に適した組み合わせが必要となる。フラックスレス法で はフラックス法に比べて酸化皮膜除去能力が低いので, 炉内䨌囲気, 特に酸素濃度と露点が大きな影響をもつ. もちろん, 両者ともに低い程良い. 䨌囲気中の酸素や水 分の除去には酸化しやすい金属をゲッターとして用いる ことがある。

$\mathrm{Mg}$ には下記，式（7）および式（8）のゲッター作用 があるとされ21)，真空ろう付用アルミニウムろうには $1 \mathrm{mass} \%$ 程度の $\mathrm{Mg}$ が添加される. 蒸気圧の高い $\mathrm{Mg}$ が 真空中で蒸発しゲッター作用をする．また，アルミニウ ムろう付では式（9）も考えられている.

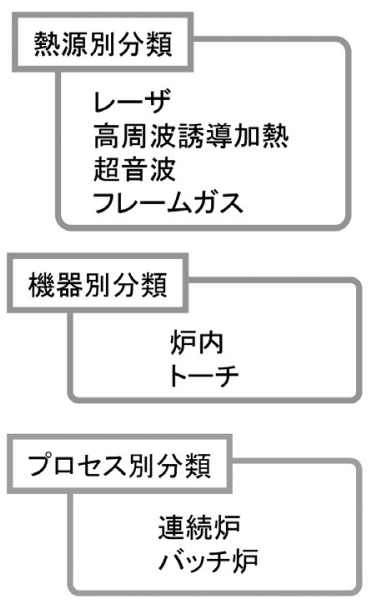

図 10

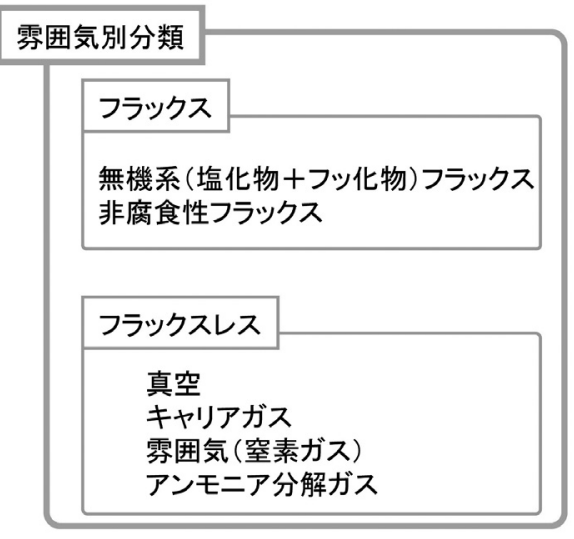

ろう付の分類方法の例 


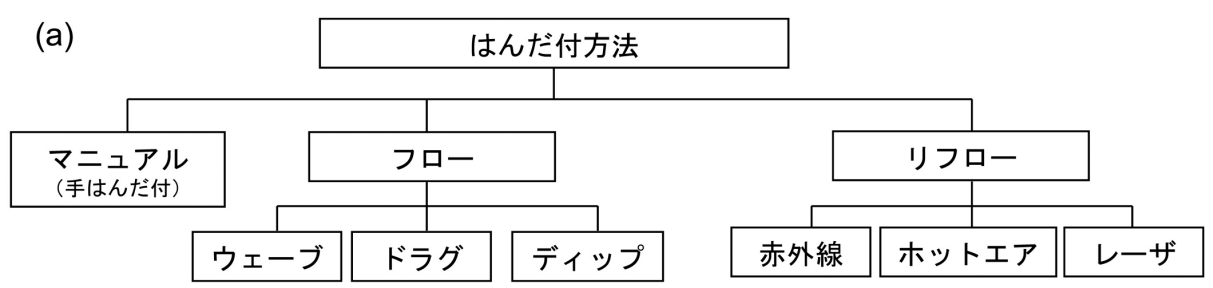

(b)

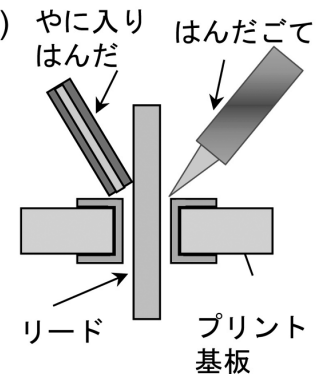

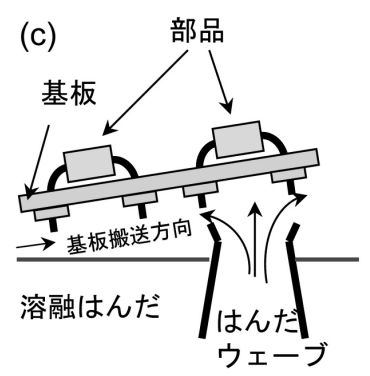

(d)

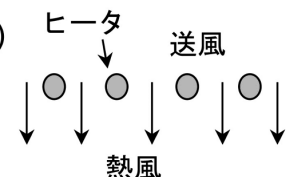

熱風

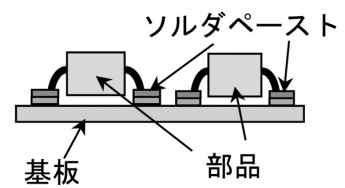

図 11 主要はんだ付方法の分類 (a) とマニュアル (b), ウェーブ (c) およびリフロー（d）の各方法を示す模式図

$$
\begin{aligned}
& \mathrm{Mg}+1 / 2 \mathrm{O}_{2} \rightarrow \mathrm{MgO} \\
& \mathrm{Mg}+\mathrm{H}_{2} \mathrm{O} \rightarrow \mathrm{MgO}+\mathrm{H}_{2} \\
& \mathrm{Mg}+1 / 3 \mathrm{Al}_{2} \mathrm{O}_{3} \rightarrow \mathrm{MgO}+2 / 3 \mathrm{Al}
\end{aligned}
$$

ろう付方法や応用などに関しては単行本を参照願いた (22-24).

\section{5. マイクロソルダリング}

図11にマイクロソルダリング方法の分類を示す。はん だごてを使用するマニュアルはんだ付，溶融はんだを熱 源と接合材として使用するフローはんだ付およびソルダ ペースト（JIS Z 3284参照）を印刷塗布して炉内はんだ付 するリフローはんだ付の三つが主要工法であり，簡単な 模式図を併示した。

プリント基板上のはんだ付は，マニュアルはんだ付や フローはんだ付の挿入実装から，リフローはんだ付で行 われる表面実装へと進化し，現在では，はんだバンプを 用いるバンプ実装が増えている。2006年 7 月以降， EU (欧州連合) の $\mathrm{RoHS}^{8}$ （有害物質規制）に対応して，鉛フ リーはんだ実装25, 26)時代となっており，エレクトロニクス パッケージの微細微小化も継続していることから，マイ クロソルダリングや微細接合技術の向上は益々重要にな つている4-7,27-31).

\section{6。 ま め}

ろう付およびはんだ付（ろう接）は，安価な簡便接合 法としてトーチを熱源として管の接合などに多用されて きたが，このような簡便接合法は継手強度や耐食性など が十分ではなく, 継手の高信頼性が重視されるハイテク 製品へは適用しがたく，いわゆるローテクと認識されて 久しい。このため, 手作業のトーチ接合は日本での重要 性は薄れてきており，その技術の伝承が問題視される状 況といってもよい。一方で，ろう接は多点一括接合技術 としての特性を生かし, 熱交換器類やプリント基板への
部品搭載技術として不可欠の接合法として進化してきて いる. 日本の優れたアルミニウム素材製造技術とろう付 技術が一体化して, 薄肉・軽量・高性能・高耐食性の熱 交換器製造を可能としており，自動車工業の隆盛を支え ている. 同様に, 微細・高信頼性プリント基板実装技術 は日本の電気・電子産業の進化の源泉である.アルミニ ウムろう付では環境対応の炭酸ガス冷媒用高耐圧熱交換 器の製造，微細実装では鉛フリーはんだ対応の微細バン プ実装や継手の耐衝撃性改善要求など，両技術とも一層 の進化が期待されている. 接合技術の困難性が上がるほ ど，日本の優れた素材や接合技術が一層顕著になるので, これらの技術は日本の基幹製造業を支えるために今後と も開発努力が必要である.

\section{参考文献}

1) JIS Z 3001-3（2008）溶接用語－第 3 部：ろう接.

2）軽金属溶接構造協会：アルミニウムブレージングハンドブ ック (改訂版)，（社）軽金属溶接構造協会, (2003), 3-12.

3) 竹本 正, 佐藤了平：高信頼度マイクロソルダリング, 工 業調査会，(1991).

4) 竹本 正：鉛フリーはんだの信頼性と JIS 化および海外標 準化動向, 実装技術ガイドブック 2005, 電子材料, 44-7 別冊 (2005), 17-25.

5) 竹本 正：電子機器実装における鉛フリーはんだ化の進展 状況，真空，48-6 (2005), 372-377.

6) 竹本 正：鉛フリーはんだ実装技術の最新状況と課題, 高 温学会誌, 32-4 (2006), 192-199.

7）竹本 正: 鉛フリーはんだ技術の現状，溶接学会誌，75-7 (2006), 37-42.

8) Official Journal of the European Union, Directive 2002/95/EC of the Europian parliament and of the Council of $27 \mathrm{Jan} .2003$ on the restriction of the certain hazardous substances in electrical and electronic equipment, Feb. 13, (2003), L 37/19-L37/23, L 37/24-L37/38.

9) T. Takemoto: Introduction of JIS Related to Lead-free Solder and Soldering, Proc. $20056^{\text {th }}$ International Conference on Electronics Packaging Technology, August 30-September 2, Shenzhen, China, (2005), 8-12.

10) E. A. Moelwyn-Hughes, The Kinetics of Reaction in Solution, 
2nd. Ed., Clarendon Press, Oxford, (1947), 374-377.

11) Y. Shoji, S. Uchida, and T. Ariga, Dissolution of Solid Copper Cylinder in Molten Tin-Lead Alloys under Dynamic Conditions, Met. Trans. B, Vol. 13B-3, (1982), 439-445.

12) I. Okamoto and T. Yasuda: Selection of Optimum $\mathrm{Cu}$ Content in $\mathrm{Cu}$ Bearing Tin-Lead Solder, Trans. JWRI, 15-2 (1986), 245-252.

13) A. Sharif, Y. C. Chan: Liquid and solid state interfacial reactions of $\mathrm{Sn}-\mathrm{Ag}-\mathrm{Cu}$ and $\mathrm{Sn}-\mathrm{In}-\mathrm{Ag}$-Cu solders with Ni-P under bump metallization, Thin Solid Films, 504-1, 2 (2006), 431435 .

14) M. N. Islam, Y. C. Chan, A. Sharif and M. J. Rizvi: Effect of 9 wt.\% In addition to $\mathrm{Sn} 3.5 \mathrm{Ag} 0.5 \mathrm{Cu}$ solder on the interfacial reaction with the $\mathrm{Au} / \mathrm{NiP}$ metallization of $\mathrm{Cu}$ pads, J. Alloys and Compounds, 396-1, 2 (2005), 217-223.

15) A. Sharif, Y. C. Chan. M. N. Islam and M. J. Rizvi: J. Alloys and Compounds, 388-1 (2005), 75-82.

16) Y-W. Yen, W-T. Chou, Y. Tseng, C. Lee and C-L. Hsu: Investigation of Dissolution Behavior of Metallic Substrates and Intermetallic Compound in Molten Lead-free Solders, J. Electronic Materials, 37-1 (2008), 73-83.

17) Y. C. Chan, Alex C. K. So and J. K. L. Lai: Growth kinetic studies of $\mathrm{Cu}-\mathrm{Sn}$ intermetallic compound and its effect on shear strength of LCCC SMT solder joints, Materials Sci. and Eng., B55-1 (1998), 5-13.

18）岡本郁男, 竹本 正, 内川 啓: 金属間化合物を含むアル ミニゥムのろう付性と溶融ろうとの反応, 軽金属溶接, 20-2 (1982), 53-58.
19) 竹本 正, 岡本郁男：3004合金の長時間フラックスレスろ う付試験，軽金属，35-7 (1985), 405-413.

20) 宮崎 誠, 竹本 正, 松縄 朗: 円柱周囲に形成されるメ ニスカス形状の解析 溶接学会論文集，15-4 (1997), 674680.

21) J. R. Terill, C. N. Cochran, J. J. Stokes and W. E. Haupin: Understanding the Mechanisms of Aluminum Brazing, Weld. J., 50-10 (1971), 833-839.

22) D. M. Jacobson and G. Humpston: Principles of Brazing, ASM International, Ohio, USA, (2005).

23) M. Schwarts: Brazing, Second Edition, ASM International, Ohio, USA, (2003).

24) G. Humpston and D. M. Jacobson: Principles of Soldering and Brazing, ASM International, Ohio, USA, (1993).

25) J. W. Evans: A Guide to Leas-free Solders, Physical Metallurgy and Reliability, Springer, USA, (2007).

26) J. Bath: Lead-Free Soldering, Springer, USA, (2007).

27) S. Ganesan and M. Pecht: Lead-free Electronics, WileyInterscience Publication, USA, (2006).

28) G. Humpston and D. M. Jacobson: Principles of Soldering, ASM International, Ohio, USA, (2004).

29) Y. Zhou: Microjoining and nanojoining, Woodhead Pub. Ltd., Cambridge, England, (2008).

30) 竹本 正：鉛フリーはんだ特性に対応した評価試験方法, 電子材料, Vol. 47-1 (2008), 26-32.

31) K-N Tu: Solder Joint Technology, Materials, Properties, and Reliability, Springer, USA, (2006). 